\begin{tabular}{|l|l|l||}
\hline \multicolumn{2}{|c|}{ PublisherInfo } \\
\hline \hline PublisherName & $:$ & BioMed Central \\
\hline \hline PublisherLocation & $:$ & London \\
\hline \hline PublisherImprintName & $:$ & BioMed Central \\
\hline \hline
\end{tabular}

\title{
News group for critical care nurses
}

\begin{tabular}{|l|l|l||}
\hline \multicolumn{2}{|c||}{ ArticleInfo } \\
\hline \hline ArticleID & $:$ & 4244 \\
\hline \hline ArticleDOI & $:$ & $10.1186 /$ ccf-1999-webreport9 \\
\hline \hline ArticleCitationID & $:$ & webreport9 \\
\hline \hline ArticleSequenceNumber & $:$ & 32 \\
\hline \hline ArticleCategory & $:$ & Web report \\
\hline \hline ArticleFirstPage & $:$ & 1 \\
\hline \hline ArticleLastPage & $:$ & 2 \\
\hline \hline & & RegistrationDate : 1999-5-21 \\
\hline ArticleHistory & $:$ & OnlineDate \\
\hline \hline ArticleCopyright & $:$ & Current Science Ltd1999-5-21 \\
\hline \hline ArticleGrants & $:$ & \\
\hline \hline ArticleContext & $:$ & 1305433 \\
\hline \hline
\end{tabular}




\section{Overview}

The ccn-1 is a new news group dealing with critical care nursing issues. All medical disciplines are encouraged to join. Members can post and receivemessages that relate to general and critical care, advanced practice,emergency and education. Occasional postings by the moderator will showlinks to new or interesting healthcare-related sites. List moderator:Mark Ambler, RN, BSN, CCRN.

\section{Other comments}

The site is updated continuously.

\section{Evaluation}

To subscribe type ccn-l-subscribe@egroups.com in the address lineleaving blank the subject and message lines.Messages and emails can also be read on the web at http://www.egroups.com/list/ccn-1

\section{References}

1. Critical Care Nursing List. [http://www.egroups.com/list/ccn-l]

This PDF file was created after publication. 